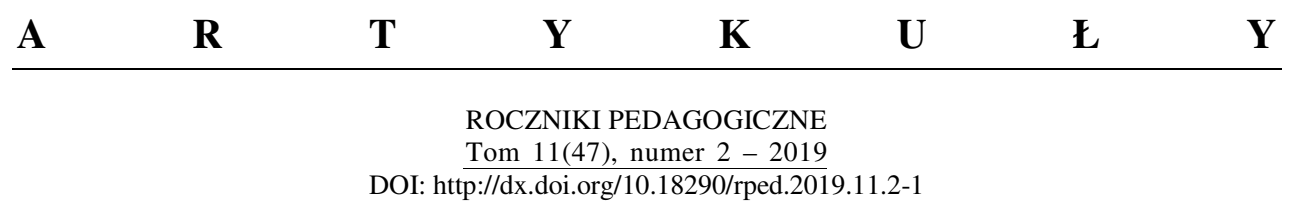

TERESA PARCZEWSKA

\author{
FENOMENOLOGIA W PEDAGOGICE \\ UWARUNKOWANIA, MOŻLIWOŚCI I POTRZEBY
}

\author{
WPROWADZENIE
}

Fenomenologia to nie jedyny, ale jeden $\mathrm{z}$ możliwych sposobów uprawiania badań jakościowych. W sytuacji, gdy badacz przenosi założenia fenomenologii filozoficznej na grunt pedagogiki, w centrum swoich zainteresowań umieszcza subiektywne doświadczenie świata, w którym żyje człowiek. W Polsce fenomenologiczne podejście badawcze jest słabo rozpowszechnione, aczkolwiek można zauważyć coraz większe zainteresowanie badaczy tą metodą. Do polskich filozofów, klasyków wykorzystujących w swoich studiach metodę fenomenologiczną oraz wyniki badań, które są w dość szerokim zakresie wykorzystywane przez polskich pedagogów ogólnych, zajmujących się filozofią wychowania, należą niewątpliwie: Roman Ingarden, Władysław Stróżewski, Józef Tischner, Władysław Cichoń, Jacek Filek.

Konstytutywnym celem fenomenologicznie zorientowanej pedagogiki jest poznanie doznań i przeżyć danej osoby oraz tego, w jaki sposób jawi się jej świat. Fenomenolog $\mathrm{w}$ projekcie badawczym może korzystać $\mathrm{z}$ wielu metod, które umożliwią pozyskanie bogatego i różnorodnego opisu konkretnego doświadczenia bądź narracji o doświadczeniu. Obszar badań fenomenologii obejmuje wszystko to, co dane jest w świecie, to, co się w nim znajduje, to, co się w nim prezentuje. Posługiwanie się metodą fenomenologiczną w badaniach pedagogicznych nie jest łatwe, nie składa się z gotowego wykazu reguł i zestawu rozwiązań. Oprócz

Dr hab. TeResa PARCZEwSKA, prof. UMCS - Wydział Pedagogiki i Psychologii UMCS, Lublin; e-mail: terpar@wp.pl 
pogłębionych studiów teoretycznych, czy też uczestnictwa w pracach doświadczonych zespołów badawczych, niezbędne wydaje się podejmowanie samodzielnych prób mających na celu poszukiwanie odpowiedzi na pytania o świat i człowieka. Niniejszy artykuł podkreśla istotę badań fenomenologicznych, zwraca uwagę na uwarunkowania, możliwości i potrzeby aplikowania fenomenologii Edmunda Husserla do teorii i praktyki badawczej w pedagogice.

\section{CZYM JEST FENOMENOLOGIA?}

Termin „fenomenologia” nie został sformułowany przez Husserla, pojawił się w filozoficznym dyskursie znacznie wcześniej (Ryk, 2011, s. 22). Według Ingardena (1974, s. 7), rok 1900 może być uważany za początek pierwszej fazy fenomenologii w dzisiejszym tego słowa znaczeniu, która trwała do około 1914 roku - do wydania przez Husserla kolejnego dzieła: Idee czystej fenomenologii $i$ fenomenologicznej filozofii.

Fenomenologia to nauka o zjawiskach (Ablewicz, 1994, s. 57). Termin ten oznacza „badanie fenomenów, to znaczy tego, co pojawia się w świadomości, tego, co jest dane. Idzie o przebadanie tej danej, rzeczy samej, którą się spostrzega, o której się myśli, o której się mówi, unikając wysuwania hipotez zarówno co do związku, jaki łączy fenomen z bytem, którego ten jest przejawem, jak i co do związku, jaki go zespala z Ja, dla którego jest fenomenem”(Lyotard, 2000, s. 7). Pojęcie „fenomen” pochodzi od greckiego phainomenon i oznacza to, co się jawi, co jasno się przed nami ukazuje. W phainomenon mieści się też słowo phos, czyli zawierać światło (Ablewicz, 1994, s. 57). Oznacza to, że fenomen, dzięki zawartemu w sobie światłu, ma zdolność jasnego prezentowania się. Aby dostrzec owo światło i ukazujący się w nim fenomen, trzeba w swoisty sposób się na nim skoncentrować. Sformułowana przez Husserla zasada fenomenologów „z powrotem do rzeczy samej" nakazuje, by skupić się nie na całej dotychczasowej wiedzy o wychowaniu, stereotypach, poglądach i oczekiwaniach, lecz na tym, co owa rzecz ma do powiedzenia sama w sobie. „Nie wiedza o niej, tylko ona sama”(Husserl, 1967, s. 78-79). W filozofii współczesnej mianem fenomenologii określa się kierunek filozoficzny stworzony przez Edmunda Husserla, który pragnął uczynić z filozofii naukę ścisłą, naukę o rzeczy samej, którą się postrzega, o której się mówi i podstawę nauk szczegółowych (Schütz, 1989, s. 107-130). 


\section{POWINNOŚCI FENOMENOLOGA I SWOISTOŚĆ PEDAGOGIKI FENOMENOLOGICZNEJ}

Według Maxa Schelera (1987), fenomenologia nie jest nazwą nowej nauki czy nowej metody, jest nazwą pewnej postawy duchowego patrzenia. Jest zasadniczo różna od obserwacji. Fenomenolog nie stoi i nie „ogląda” z różnych stron rzeczy. Musi „wziąć udział” w akcie poznawania wyrażonym w najbardziej bezpośrednim obcowaniu $\mathrm{w}$ przeżyciu $\mathrm{z}$ samym światem, tzn. rzeczami, które pragnie poznać. Mówi o tym, co naprawdę widzi - w sensie dosłownym, pochodnym lub przenośnym - a nie podsuwa pod widziane treści różne konstrukcje myślowe (Cyrańska, 2002, s. 44). W badaniach fenomenologicznych badacz nie zajmuje pozycji dominującej. Charakterystyczna dla większości realizowanych na gruncie pedagogiki projektów badawczych relacja: podmiot poznający-przedmiot poznania, zostaje zastąpiona dynamiczną relacją współpoznania, w ramach której badacz i badany stają się współbadaczami. Powinnością fenomenologa jest postawić się na miejscu podmiotu, który próbuje odnaleźć drogę swojego życia na tym świecie, a przede wszystkim pamiętanie o tym, że to otoczenie, pod którego jest wpływem i do którego się dostosowuje, stanowi jego świat, a nie obiektywny świat nauki. Racjonalność pedagogiki fenomenologicznej - jak zauważa Ryk (2011, s. 194) - wypływa z przekonania, iż wszelka działalność pedagogiczna jest zasadniczo aktem o charakterze duchowym. Jej głównym zadaniem jest „odsłonięcie tożsamości świata ducha jako rzeczywistości, która poprzedza wszelkie działanie. Jest to działanie niezwykle odpowiedzialne, bowiem staje się prawdziwą troską o ludzkie człowieczeństwo" (tamże). Pedagogika fenomenologiczna czyni ducha ludzkiego polem systematycznego doświadczania i badania, a jej celem jest pragnienie wyjaśnienia relacji pomiędzy samorozumieniem ducha wychowawcy, ducha wychowanka (podmiotów wychowania), otaczającego ich świata życia codziennego i prawdy. 


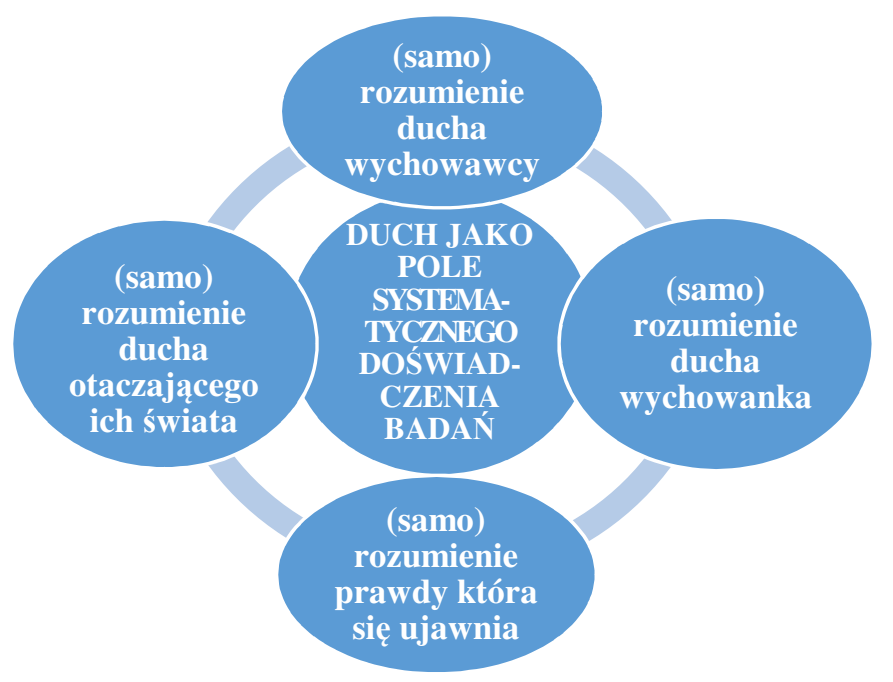

Źródto: A. Ryk, 2011, s. 194.

W przekonaniu Ryka, pedagogika fenomenologiczna ukazuje, że istotnym elementem $\mathrm{w}$ procesie wychowania jest akt samorozumienia podmiotu, który buduje sposób rozumienia samego siebie na podstawie już wcześniej posiadanego samorozumienia. Samorozumienie nie jest kategorią stałą, bowiem pod wpływem dynamicznie zmieniającego się otoczenia ulega transformacji. W opinii niektórych badaczy kategoria ta we współczesnej pedagogice jest często niedoceniana: „Nie tylko badać, ale i uwzględniać naturalne nastawienie wychowanka, rozpoczynając jakikolwiek proces wychowania czy nauczania"(Ryk, 2011, s. 196). Zarówno nauczanie jak i wychowanie stanowią przenikające się rzeczywistości, warunkujące się wzajemnie i mające znaczenie dla samorozumienia siebie i świata.

\section{ETAPY BADANIA W PERSPEKTYWIE FENOMENOLOGICZNEJ}

Badanie pedagogiczne można określić mianem fenomenologicznego, kiedy dane zbierane w jego ramach mają formę wypowiedzi w pierwszej osobie. Pro- 
cedura badawcza zyskuje swoje metodologiczne uzasadnienie tylko wtedy, gdy do oczekiwanej wiedzy dochodzi się poprzez swobodne opisy umożliwiające odkrycie istoty fenomenu. Jednak uzyskanie opisów to tylko jedna $\mathrm{z}$ części badania fenomenologicznego. Pozostałe jego etapy określają niżej wymienione procesy (por. Moustakas, 2001, s. 106-126):

1. Epoché (gr.) - [zawieszenie, wzięcie w nawias] - aby poznać prawdę o rzeczywistości, należy na pewien czas zawiesić przekonanie o istnieniu tego świata i przyjąć postawę intelektualno-egzystencjalną, postawę wolną od uprzedzeń. Jako badacz koncentruję się na określonej sytuacji, osobie albo kwestii w sposób bezpośredni. Biorę w nawias (zawieszam) inne sposoby rozumienia czy interpretowania badanej rzeczywistości, wchodzę bezpośrednio w relację z tym, co chcę badać. Epoché to „przygotowanie do wywodzenia nowej wiedzy, a również jako przeżycie samo $\mathrm{w}$ sobie, proces odsuwania od siebie upodobań, uprzedzeń, predyspozycji, i zarazem przyzwolenia, aby rzeczy, wydarzenia i ludzie wchodzili od nowa do świadomości, i aby patrzeć na nie i rozumieć je, jakby po raz pierwszy”(Moustakas, 2001, s. 107). Oczywiste jest, że nigdy nam się nie uda osiągnąć absolutnej czystości spojrzenia. Dlatego owa granica zawieszenia jest określana nieco enigmatycznie: tak daleko, jak to możliwe. W sytuacji, gdy epoché ,jest praktykowane mądrze, dostosowane do realiów i dokonywane $\mathrm{z}$ determinacją, aby odsunąć nasze przedwczesne osądy, to pełniej ujawni się rzeczywista natura i esencja rzeczy, i pozwoli nam uzyskać czystość i światło dla wiedzy i prawdy"(Moustakas, 2001, s. 113).

2. Redukcja fenomenologiczna - [(reducere (łac.) sprowadzić coś do czegoś], sprowadzenie rzeczywistości/przedmiotu, który chcę badać, do fenomenu, czyli do tego, jak on się jawi we mnie samym. Celem jest dotarcie do istoty zjawiska; odkrycie istotnych elementów świata życia. Od epoché rozpoczyna się dochodzenie do poznawania rzeczy, do uzyskania nastawienia na ich dostrzeganie tak jak się jawią, do powrotu do rzeczy samych, wolnych od przedwczesnych osądów i pejoratywnych uprzedzeń. Założenie to wyrażone zostało przez Husserla pod postacią „,zasady wszystkich zasad”. Jej treść głosi, że „każda źródłowo prezentująca naoczność jest źródłem prawomocności poznania, że wszystko, co się nam w 'intuicji’ źródłowo (by się tak wyrazić: w swej cielesnej rzeczywistości) przedstawia, należy po prostu przyjąć jako to, co się prezentuje, ale także jedynie w takich granicach, w jakich się tu prezentuje”(Husserl, 1967, s. 78-79). Redukcja prowadzić ma zatem do bezpośrednio oczywistej naoczności, w związku z czym uznaje ją Husserl (1974, s. 254) za „niewątpliwie prawomocną (gültig) fundamentalną metodę najbardziej pierwotnego określania sensu [...]". Zadaniem redukcji 
fenomenologicznej jest „opisanie w języku teksturalnym właśnie tego, co ktoś widzi, nie tylko pod względem zewnętrznych obiektów, ale również wewnętrznych aktów świadomości, przeżycia jako takiego, rytmu i relacji pomiędzy fenomenem i Ja. Jakości doświadczenia stają się centrum skupienia uwagi”'(Moustakas, 2001, s. 114). Jak dalej stwierdza badacz: „takie zadanie nakazuje, abym patrzył i opisywał, ponownie spoglądał i opisywał, przyglądał się raz jeszcze i opisywał, ale zawsze w nawiązaniu do jakości teksturalnych [...]"(tamże). Pojawia się wówczas refleksyjny proces skierowany na uchwycenie pełnej natury fenomenu. Refleksja staje się bardziej precyzyjna i bogatsza, kiedy wznawiamy nieustannie uwagę i spostrzeganie, dodając nowe punkty widzenia. Zatem, redukcja fenomenologiczna, to nie tylko sposób patrzenia, ale jednocześnie metoda wsłuchiwania się ze świadomą i rozmyślną intencją otwierania się na zjawiska jako fenomeny, na przynależnych im prawach, stosownie do ich własnych tekstur i sensów. Jednym z wymiarów redukcji fenomenologicznej jest proces horyzontalizacji (Moustakas, 2001, s. 119). W żadnej sytuacji nie możemy w pełni wyczerpać przeżywania rzeczy, bez względu na to ile razy rozpatrujemy je lub oglądamy, bowiem możliwość odkryć jest nieograniczona. Żaden horyzont nie trwa bez końca, za każdym razem powstaje nowy, kiedy zanika poprzedni.

Docelowym wyzwaniem w redukcji fenomenologicznej jest „konstrukcja pełnych teksturalnych opisów doświadczenia. Taki opis, biorąc początek od epoché i biegnąc poprzez proces powrotu do samej rzeczy, w stanie otwartości i wolności, ułatwia wyraźne spostrzeganie, czyni możliwym tożsamość i zachęca do wielokrotnego przyglądania się czemuś, co prowadzi do głębszych warstw sensu (Moustakas, 2001, s. 120). W procesie tym następuje przeplatanie się osoby, świadomego przeżycia i fenomenu. W wyniku objaśnienia fenomenu ma miejsce rozpoznanie i opis jakości. Jak podkreśla Moustakas (2001, s. 120): „Tę samą wartość przyznajemy każdemu spostrzeżeniu, wiążemy tematycznie nie powtarzające się składniki przeżycia, wyprowadzamy z nich pełny opis".

Podsumowując, etapy redukcji fenomenologicznej zawierają: wzięcie w nawias, horyzontalizację, grupowanie horyzontów w tematy oraz organizowanie horyzontów i tematów w spójny opis teksturalny zjawiska.

3. Wyobrażeniowe uzmiennianie (imaginacyjna wariacja) - czyli, poszukiwanie możliwych sensów poprzez wykorzystanie wyobraźni, zmianę układów odniesienia, podchodzenie do fenomenu z różnych perspektyw (Moustakas, 2001, s. 122). Dążeniem jest dojście do opisu strukturalnego przeżycia, czynników leżących u jego podłoża oraz czynników ułatwiających jego powstanie, które objaśniają to, co jest przeżywane: Jak i co mi się jawi? Za pośrednictwem waria- 
cji imaginacyjnej badacz ma sposobność zrozumienia, że do prawdy nie prowadzi jedna droga, ale pojawiają się niezliczone ewentualności, które są blisko powiązane $\mathrm{z}$ istotami, sensami przeżycia.

4. Syntezy znaczeń i esencji - to finalny krok w fenomenologicznym procesie badawczym, który polega na scalaniu podstawowych teksturalnych i strukturalnych opisów w jednolitą wypowiedź o istocie przeżycia jako całości, czyli ustalenie wiedzy o świecie (Husserl, 1976). Istota - jak rozumie to pojęcie Husserl - oznacza to, co jest wspólne lub uniwersalne, warunek lub jakość, bez której rzecz nie byłaby tym, czym jest. Zamierzeniem opisu jest nie tylko utrwalenie wyników badań, lecz nade wszystko takie ich przekazanie innym, by czytający mógł znaleźć się - jak podkreśla Cyrańska (2001, s. 38) - ,w obliczu” opisywanego przedmiotu. Opis ma nie tyle komunikować te wyniki, ale przede wszystkim naprowadzać czytelnika na takie samo widzenie przedmiotu, jakie ma opisujący fenomenolog.

Bez zrozumienia natury, sensu i istoty epoché, redukcji fenomenologicznej, imaginacyjnej wariacji i syntezy, nie sposób jest prowadzić badania fenomenologiczne.

\section{MOŻLIWOŚCI I OGRANICZENIA PROWADZENIA BADAŃ FENOMENOLOGICZNYCH - WŁASNE DOŚWIADCZENIA}

Utrudnienia, które występują najczęściej w trakcie prowadzonych badań, można podzielić na zewnętrzne (związane ze środowiskiem) oraz wewnętrzne tkwiące w osobach badanych i samym badaczu. Wśród zewnętrznych można wymienić: brak zainteresowania placówek oświatowych i rodziców tego typu badaniami i w konsekwencji odmowa przeprowadzenia badań oraz dyskomfortowe warunki lokalowe, które uniemożliwiają prowadzenie badan $\mathrm{z}$ dziećmi w atmosferze bezpieczeństwa, spokoju i zaufania.

Utrudnienia tkwiące $\mathrm{w}$ osobach badanych wynikają głównie $\mathrm{z}$ ich usposobienia. Niektórym respondentom towarzyszy nieśmiałość lub brak zaufania do badacza. W przypadku badań prowadzonych z małymi dziećmi ograniczeniem jest niski poziom kompetencji narracyjnych.

Mając na uwadze ograniczenia tkwiące w badaczu, należy głównie zwrócić uwagę na trudności uzyskania stanu epoché. Jak taki stan badacz może osiągnąć? Schleidt (za: Moustakas, 2001, s. 111) odpowiada: „Konieczna jest wprost niewyobrażalna ilość czasu, spędzona na bezstronnej obserwacji, aby zyskać zdolność do wyodrębnienia Postaci od tła. Do takiego uporczywego wysiłku zdolni są jedynie ci, których wzrok, przez w pełni irracjonalne czerpanie rozkoszy z piękna obiektu, pozostaje przykuty przez przedmiot”. Każdy badacz, praktykując epoché, 
powinien wielokrotnie przyglądać się swoim myślom dotyczącym osób, sytuacji i kwestii, które stanowią przedmiot jego dociekań, za każdym razem powinien odkładać na bok swoje uprzedzenia i przedwczesne osądy aż do momentu odczucia wewnętrznej gotowości poznania sytuacji, kwestii czy osoby takimi, jakimi są. W opinii badaczy rzadko uzyskujemy epoché w doskonałej postaci, aczkolwiek regularna, intensywna praktyka procesu epoché zwiększa kompetencje do „uzyskania stanu pozbawionego supozycji, do pozostawania otwartym na przyjmowanie czegokolwiek, co jawi się w świadomości, jako takiej” (Moustakas, 2001, s. 113). Podobną opinię wyraża również Garfinkel (1984, s. 206) twierdząc, że reguły interpretacyjne, obowiązujące w naukowym teoretyzowaniu, wymagają zawieszenia sądów o trafności tej wiedzy badacza, którą nabył przez fizyczne i społeczne uczestnictwo w rzeczywistym świecie.

Inne zagrożenie, będące udziałem badacza, tkwi w tym, iż pod wpływem wcześniejszych doświadczeń może on zbudować w swoim umyśle pewien model zachowań osoby badanej, a będąc w nowej sytuacji będzie doszukiwać się tych elementów, które upodabniają ją do sytuacji znanych z przeszłości, „może poszukiwać $\mathrm{w}$ swych przeszłych doświadczeniach takich recept, które wedle jego obecnego mniemania doprowadziły do tych praktycznych rezultatów, które teraz stara się wywołać" (Garfinkel, 1984, s. 201). Takiego typu zachowania są manipulacją i mogą spowodować z góry zaplanowany rezultat. Dla poprawności prowadzonych badań ważna jest także wiedza badacza (to, co wie, sposób, w jaki wie) o badanym problemie, która stanowi integralny składnik jego społecznej kompetencji, i którą należy posiadać (tamże, s. 206). Problem może stanowić również ukryta wiedza (Garfinkel 1984, s. 209), będąca konstytutywnym składnikiem społecznych interakcji. Jak twierdzi autor, ,wiedza, którą dzielimy z innymi, jest zawsze zabarwiona tym, co zachowujemy tylko dla siebie, tym co ukrywamy przed innymi"(tamże). W tej sytuacji bardzo istotny podczas rozmowy jest bezpośredni kontakt badacza z osobą badaną, nazywany przez Bergera i Luckmanna (1983, s. 62) kontaktem twarzą w twarz. Żeby ustrzec się przed możliwością odkrywania artefaktów, wnoszonych przez osoby prowadzące badania, konieczne jest permanentne podawanie $\mathrm{w}$ wątpliwość ustaleń empirycznych.

\section{DYSKUSJA I WNIOSKI}

Pomimo różnych ograniczeń rola fenomenologii i metody fenomenologicznej w pedagogice - podobnie jak hermeneutyki - wydaje się być szczególna, ponieważ pozwala prowadzić badania na poziomie teoretycznych i metateoretycznych 
studiów, umożliwia poznawanie rzeczywistości pedagogicznej, a dodatkowo wspomaga rozwój osobisty i zawodowy badacza.

Badania fenomenologiczne w sposób znaczący rozszerzają dotychczasowe pole badań, w tym również o charakterze pedagogicznym. Sprawiają - jak podkreśla Ryk (2011, s. 193) - iż pedagogika staje się nauką hermeneutyczną, a nie hermetyczną.

Fenomenologia służy jako metoda, ale zarazem poprzez odsłonięcie i wskazanie istoty opisywanego fenomenu pedagogicznego, nabiera rangi fundamentu wspierającego nauki pedagogiczne (Ablewicz, 1994), a dyskusje o granicach fenomenologii inspirują do wprowadzania nowych rozwiązań, wciąż pozostają jednym z najistotniejszych kół zamachowych rozwoju fenomenologii.

Jak zauważa Ablewicz (2008, s. 122): „Z punktu widzenia pedagoga, badania fenomenologiczne przeprowadzane w obszarze filozofii dostarczają znakomitego horyzontu, który umożliwia interpretację rzeczywistości wychowawczej, choćby z tej racji, że wychowanie jest wbudowane w ogólnoludzkie dzieje człowieka".

Warto i powinno się sięgać po fenomenologię w pedagogice, bowiem umożliwia ona badaczom (również nauczycielom) wpatrywanie się w świat życia codziennego, czyniąc go przejrzystym, klarownym i czytelnym. To, co w fenomenologii istotne ,nie polega na dążeniu do urzeczywistniania się w postaci jakiegoś kierunku filozoficznego. Wyżej od rzeczywistości stoi możliwość. Zrozumienie fenomenologii polega wyłącznie na ujęciu jej jako możliwości” (Heidegger, 2010, s. 59).

\section{BIBLIOGRAFIA}

Ablewicz, K. (2008). Hermeneutyka i fenomenologia a pedagogika. W: S. PALKA (red.), Podstawy metodologii badań w pedagogice (s. 103-123). Gdańsk: Gdańskie Wydawnictwo Psychologiczne.

ABLEWICZ, K. (1994). Hermeneutyczno-fenomenologiczna perspektywa badań w pedagogice. Kraków: Uniwersytet Jagielloński.

Berger, P., Luckmann, T. (1983). Społeczne tworzenie rzeczywistości. Warszawa: PIW.

CYrańsKa, E. (2001). W poszukiwaniu istoty, czyli o możliwości otwierania horyzontu badań pedagogicznych na metodę fenomenologii. W: D. URBANIAK-ZAJĄC, J. PIEKARSKI (red.), Jakościowe orientacje w badaniach pedagogicznych (s. 32-51). Łódź: Wydawnictwo Uniwersytetu Łódzkiego.

GARFINKEL, H. (1984). Racjonalne cechy działalności naukowej i potocznej. W: Kryzys i schizma. Antyscjentyczne tendencje w socjologii wspótczesnej, t.1. Warszawa: PIW.

HeIDEgGer, M. (2010). Bycie i czas. Warszawa: PWN.

HuSSERL, E. (1967). Idee czystej fenomenologii i fenomenologicznej filozofii. Księga 1, przeł. D. Gierulanka, Warszawa: PWN. 
HuSSERL, E. (1974). Idee czystej fenomenologii i fenomenologicznej filozofii. Księga 2, przeł. D. Gierulanka, Warszawa: PWN.

Moustakas, C.E. (2001). Fenomenologiczne metody badań, tłum. S. Zabielski. Białystok: Wydawnictwo Uniwersyteckie Trans Humana.

RYK, A. (2011). W poszukiwaniu podstaw pedagogiki humanistycznej. Od pedagogiki Edmunda Husserla do pedagogiki fenomenologicznej. Kraków: Impuls.

SCHELER, M. (1987). Pisma z antropologii filozoficznej i teorii wiedzy, tłum. S. Czerniak, A. Węgrzecki. Warszawa: PWN.

SchÜTZ, A. (1989). Fenomenologia i nauki społeczne. W: Z. KraSnOdĘBSKI (red.), Fenomenologia i socjologia (s. 107-130). Warszawa: Wydawnictwo PWN.

\title{
FENOMENOLOGIA W PEDAGOGICE: UWARUNKOWANIA, MOŻLIWOŚCI I POTRZEBY
}

\author{
Streszczenie
}

W badaniach pedagogicznych rzadko wykorzystuje się podejście fenomenologiczne do analizy zjawisk składających się na doświadczenie jednostki. Celem artykułu jest próba ukazania możliwości zastosowania fenomenologii Edmunda Husserla do teorii i praktyki badawczej w pedagogice. Szukano odpowiedzi na następujące pytania: Czym jest fenomenologia? Dlaczego warto zajmować się fenomenologią? Czy można wykorzystać fenomenologię jako „szkołę myślenia” w teorii pedagogicznej i w jaki sposób można ją odnieść do pedagogicznej praktyki? Poczynione analizy nakłaniają do prowadzenia dalszych poszukiwań, które pomogą w sposób szeroki i wielostronny uwidocznić zakresy oraz drogi aplikacji myśli fenomenologicznej na grunt współczesnej teorii i praktyki pedagogicznej.

Słowa kluczowe: fenomenologia; Husserl; fenomenolog; pedagogika fenomenologiczna.

\section{PHENOMENOLOGY IN PEDAGOGY: DETERMINANTS, POSSIBILITIES, AND NEEDS}

\section{S u m m a r y}

Pedagogical studies rarely adopt the phenomenological approach to analyse the phenomena that make up individual experience. The goal of this article is to describe how Edmund Husserl's phenomenology could be used in the fields of pedagogical theory and practice. The paper addresses such questions as What is phenomenology? Why phenomenology is worth exploring? and Can we use phenomenology as a 'school of thought' in pedagogical theory, and how can it be applied to pedagogical practice? The analyses carried out for the purposes of this study encourage further investigation of this issue to discover where and how phenomenology could be applied in contemporary pedagogical theory and practice, and to explore it from a broad and multifaceted perspective.

Key words: phenomenology; Husserl; phenomenologist; phenomenological pedagogy. 